\title{
Impacts of the Interaction of Two Automobile Workshop Wastes on the Growth Performance and Chlorophyll contents of Vigna unguiculata (L.) and Sphenostylis stenocarpa (Harm)
}

\author{
*Ihimikaiye, S.O. and Tanee, F.B.G. \\ Department of Plant Science and Biotechnology, College of Natural and Applied Sciences, \\ University of Port Harcourt, Port Harcourt, Nigeria
}

\begin{abstract}
The interaction of two automobile workshop wastes on the growth performance of Vigna unguiculata (L.) and Sphenostylis stenocarpa (Harm) were examined. The crops were grown in soil treated with spent engine oil (SEO) and spent carbide waste (SCW) of different ratios: 0/0, $0 \mathrm{ml} / 150 \mathrm{~g}, 50 \mathrm{ml} / 100 \mathrm{~g}, 100 \mathrm{ml} / 50 \mathrm{~g}$ and $150 \mathrm{ml} / 0 \mathrm{~g}$. O/0 served as the control (no pollution) experiment. Results showed that interaction of SEO and SCW significantly $(P<0.05)$ affect the growth parameters (shoot height, stem girth, leaf area, number of leaves, biomass, root length, nodulation and chlorophyll contents) of Vigna unguiculata (L.) and Sphenostylis stenocarpa (Harm). Both crops in the untreated soil developed better than those in the treated soil. Growth reduction in the plants increase with increase in the dosage of SEO and SCW applied. Gross reduction occurred in nodulation level of $C P$ and $A Y B$ at $150 \mathrm{ml} / 0$ g, i.e. soil treated with only SEO. Data from other parameters studied also revealed higher reductions at soil treated with only SEO, followed closely by soil treated with only $S C W$. The impacts of SEO/SCW interaction at $50 \mathrm{ml} / 100 \mathrm{~g}$ and $100 \mathrm{ml} / 50 \mathrm{~g}$ on AYB and CP were less effectual than those at $150 \mathrm{ml} / \mathrm{g}$ and $0 \mathrm{ml} / 150 \mathrm{~g}$. It therefore implies that gross pollution of $S E O$ as well as $S C W$ produced more negative impact on $A Y B$ and $C P$ than mild combine ratios of the pollutants.
\end{abstract}

Key Words: growth, legumes, pollution, Spent engine oil, spent carbide waste.

\section{Introduction}

Healthy soil is a prerequisite for normal healthy growth and development of plants, and to a large extent crop yield. Pollution of soil with spent carbide waste (SCW) and spent engine oil (SEO) is a common occurrence in developing countries. This has created unsatisfactory conditions that impends the growth and development of plants.

The major problem of SCW and SEO in the environment stem from improper disposal of the two wastes; especially in automobile machine workshops. After serving their purposes, the wastes are too often disposed at open vacant plot, gutters or nearby vegetation close to their workshops, sooner or later the wastes get incorporated into the soil. These practices affect plant [1] because of the large amount of hydrocarbon and high toxic polycylic aromatic hydrocarbons (PAHs) contain in the oil [2]. Oil pollution in whatever form is reported to be toxic to plants and soil micro-organisms [3-5] Similarly, Tanee and Ochekwu [6] reported the toxicity of spent carbide at different concentrations to the growth and chlorophyll content of maize and groundnut. High level of calcium hydroxide, strontium and PAHs were reported as the major cause of toxicity in SCW [7].

Adenipekun et al. [2] reported that contamination of soil with SEO at very low concentration $(0.2 \%)$ has no significant effect on okra plants growth, while higher concentration adversely affects plant growth. Tanee [8] reported that carbide waste adversely affects the rate of vegetation regeneration He reported further that regeneration of vegetation was scanty at the treatment sub-plots as compared to the untreated plots. Different morphological changes in okra plant after calcium carbide application was reported by Saif-ur et al. [9]. They also noticed that internodal distance was reduced and stem thickness was increased in medium level of calcium carbide $30 \mathrm{mg} / \mathrm{kg}$ soil.

Sphenostylis stenocarpa [Africa yam bean (AYB)] and Vigna unguiculata [Cowpea (CP)] are annual dicotyledonous leguminous crops growth in Nigeria and beyond; it is grown for it fruits which are rich sources of protein; the leaves are often use as fodder for livestock. In some parts of tropical Africa, AYB being a tuberous legume is often grown because of its root which makes for local delicacy.

Despite the common incidences of improper disposal of the two wastes in Nigeria, the impacts of their interaction in different ratios on the yield of Sphenostylis stenocarpa and Vigna unguiculata has not been made certain. This work aimed at investigating the interactive impacts of SCW and SEO on the growth and development of AYB and CP which are cultivated in tropical Africa countries. 


\section{Materials And Methods}

The study was carried out in Agricultural Demonstration Screen House beside Ofrima Building Complex, University of Port Harcourt, located in the Niger Delta Area of Nigeria (Lat $4^{\circ} 65^{\circ} \mathrm{N}$; ling $7^{\circ} 05^{`} \mathrm{E}$ ). Seed grains of AYB and CP used for the study were purchased from mile three market, Port Harcourt, Nigeria. The pollutants used were sourced from an automobile workshop along Mgbuoba road, Port Harcourt. The soil sample (Sandy loam) was collected from a fallowed plot in Agriculture Demonstration Farm. 5kg soil was measured into the planting bags, perforated to allow for proper drainage and better aeration of soil. The bags were grouped into two units (A and B). Each unit had five (5) levels of pollutants dose (SEO and SCW) in ratio $0 / 0,0 \mathrm{ml} / 150 \mathrm{~g}, 50 \mathrm{ml} / 100 \mathrm{~g}, 100 \mathrm{ml} / 50 \mathrm{~g}$ and $150 \mathrm{ml} / 0 \mathrm{~g}$. Each treatment in the units was replicated five times. The experimental set up were moistened and left for one week after which four grains of AYB were planted in unit $\mathrm{A}$, and unit $\mathrm{B}$ received 4 grains of $\mathrm{CP}$ at a distance of $2 \mathrm{~cm}$ apart in the treatments. $0 / 0$ level represent the controls in the units (A and B). A week later, thinning to 2 seedlings in each bag was done to reduce overcrowding.

Data were collected on weekly basis on the following parameters: plant height, stem girth and number of leaf. Others such as nodulation, root length, biomass and chlorophyll were collected 12 week after planting (12WAP). Plant height was determined with a measuring tape calibrated in centimeters; from the soil level to each plant terminal buds. The girth was taken by placing a venier caliper at $1 \mathrm{~cm}$ above soil level of the stems and adjusted to scale; the same point was maintained till the end of the experiment to ensure accurate reading. The leaves produced were counted every 7 days [10].The Root was harvested by scattering loose the potted plants and nodules were removed and carefully counted. Root length was determined with measuring tape. Biomass (dry and fresh weights) of the plants were determined on an electronic (SF-400c) compact scale, The method used to determine the chlorophyll was based on that of Comar and Zscheile [11], the chlorophyll was extracted with aqueous acetone, transferred into ether and the optical density measured at $660 \mathrm{~nm}$ and $643 \mathrm{~nm}$. The fresh plant material were cut finely and mixed thoroughly before weighing. $5 \mathrm{~g}$ of the sample was macerated and homogenized, by adding small amounts of $85 \%$ acetone this (addition of acetone) was repeated until filtrate and washings are colourless then, were transferred to a suitable volumetric flask and diluted to volume with $85 \%$ acetone.2g of anhydrous $\mathrm{Na}_{2} \mathrm{SO}_{4}$ was added and shaken occasionally until clear solution is obtained. The optical density at $660 \mathrm{~nm}$ and $643 \mathrm{~nm}$ in $1 \mathrm{~cm}$ cells were measured using ether as a reference. If $\mathrm{C}=$ total chlorophyll in ether solution $\left(\mathrm{mg} 1-^{1}\right) . C=7.12 \times$ optical density at $660 \mathrm{~nm}+16.8 \times$ optical density at $643 \mathrm{~nm}$. Then, total chlorophyll $(\%)=$

$\mathrm{C}\left(\mathrm{mg} 1-^{1}\right) \mathrm{x}$ ether solution $(\mathrm{ml}) \mathrm{X}$ acetone extracts $(\mathrm{ml})$

$10^{4} \mathrm{x}$ acetone aliquot $(\mathrm{ml}) \mathrm{x}$ sample $\mathrm{wt}(\mathrm{g})$

Data recorded were subsequently subjected to analysis of variance and standard error mean using Microsoft excel version 2007. Least significance difference was used to separate means according to Ogbeibu [12]

\section{Results}

The results of the impact of SEO and SCW pollution of soil on the growth performance of AYB and $\mathrm{CP}$ indicated that growth and yield were inversely proportional to the levels of pollutants applied. The impact of SEO/SCW pollutant ratios on AYB and CP heights are shown in Fig. 1a and Fig. 1b. AYB and CP at $150 \mathrm{ml} / 0 \mathrm{~g}$ were significantly reduced $(\mathrm{P}<0.05)$ in height compared to their respective controls. Also height of $\mathrm{CP}$ at $0 \mathrm{ml} / 150 \mathrm{~g}$ was reduced compared to $0 / 0$. Significant difference $(\mathrm{P}<0.05)$ in height occurred in AYB that received $150 \mathrm{ml} / 0 \mathrm{~g}$ compared to treatments $0 \mathrm{ml} / 150 \mathrm{~g}, 50 \mathrm{ml} / 100 \mathrm{~g}$ and $100 \mathrm{ml} / 50 \mathrm{~g}$. The differences were levels of dosage dependent. No significant difference $(\mathrm{P}<0.05)$ occurred in AYB as well as CP height at treatments $50 \mathrm{ml} / 100 \mathrm{~g}$ and $100 \mathrm{ml} / 50 \mathrm{~g}$.

The girth of AYB and CP in treatments $150 \mathrm{ml} / 0 \mathrm{~g}$ (Fig. $2 \mathrm{a} \& 2 \mathrm{~b}$ ) shrunk significantly compare to other treatments $(\mathrm{P}<0.05)$. Also, application of high dosage of SEO and SCW significantly affect the number of leaves of CP and AYB (Fig. 3a \& 3b). The number of leaves was significantly higher $(\mathrm{P}<0.05)$ in the controls compared to $0 \mathrm{ml} / 150 \mathrm{~g}, 50 \mathrm{ml} / 100 \mathrm{~g}$, and $100 \mathrm{ml} / 50 \mathrm{~g}$ and $150 \mathrm{ml} / 0 \mathrm{~g}$ treatments. 


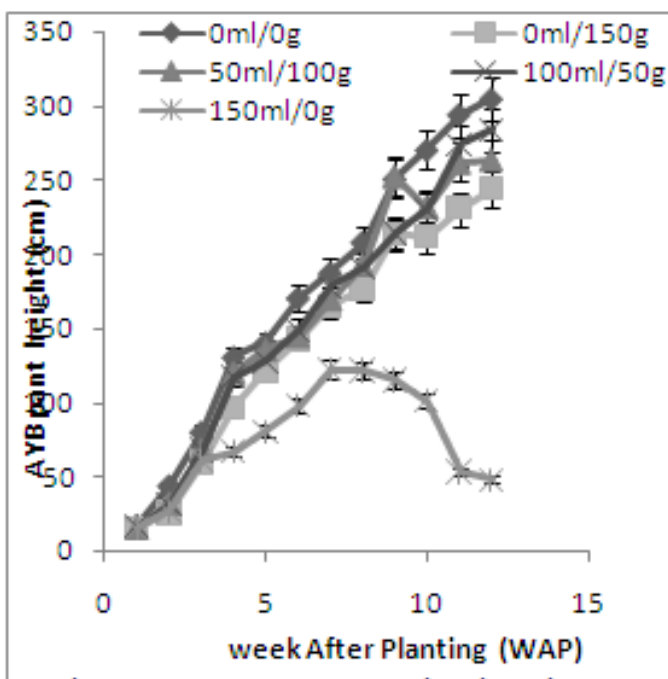

Fig. 1a: performance of AYB height in various SEO/SC treatments

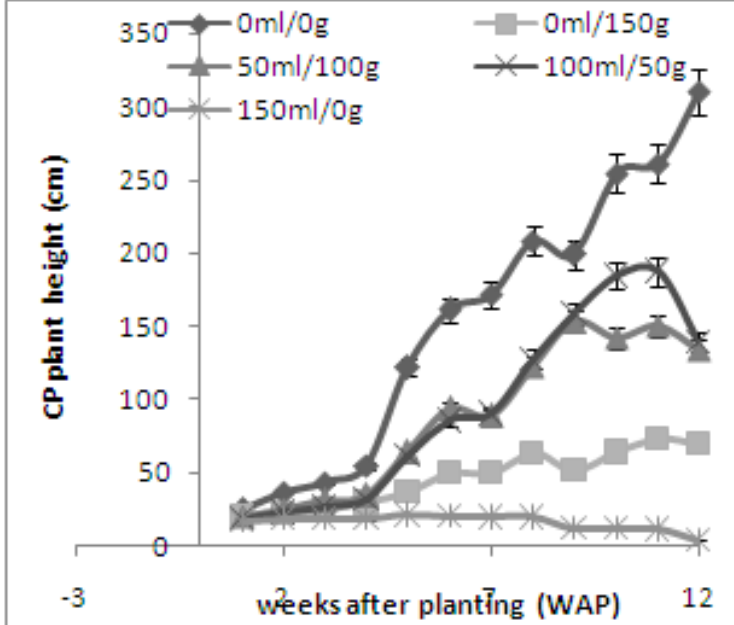

Fig.1b: performance of $\mathrm{CP}$ height in various $\mathrm{SEO} / \mathrm{SC}$ treatments

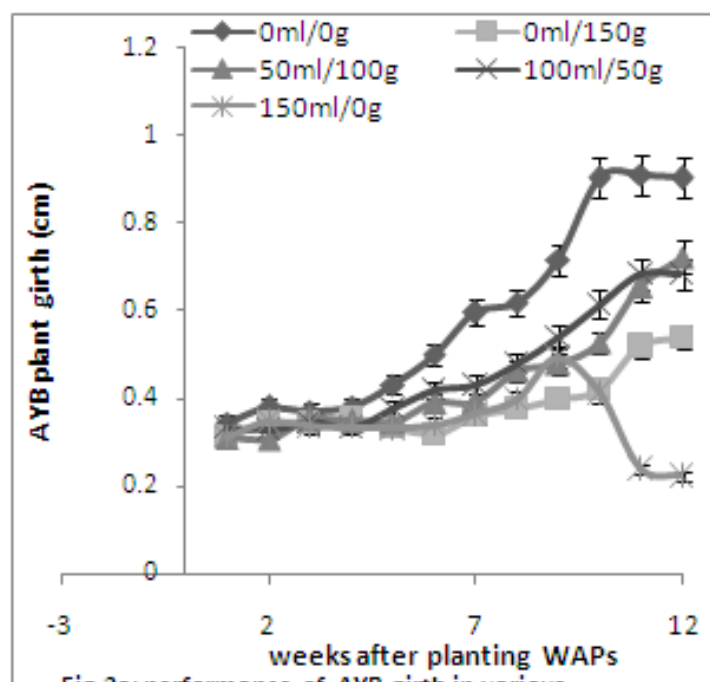

Fig.2a: performance of AYB girth in various level of SEO/SC treatments

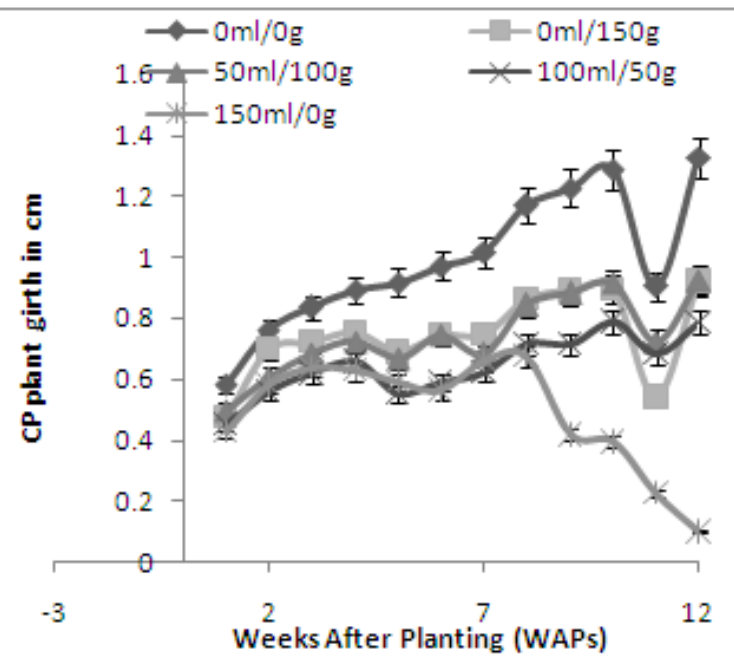

Fig. 2b: performance of $\mathrm{CP}$ girth in various level of SEO/SC treatments.

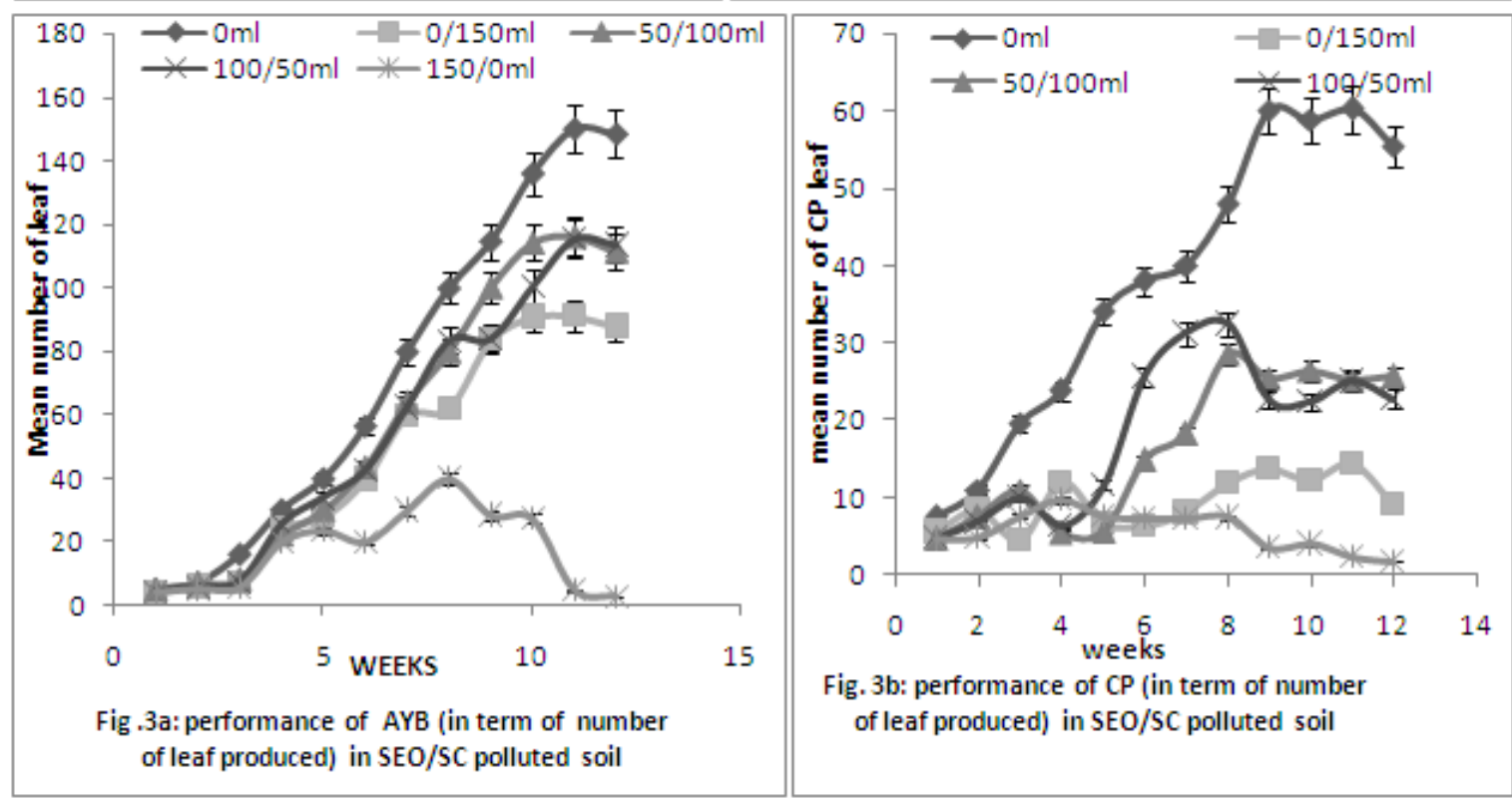


Reduction occurred in fresh weight of the plants at higher dose of SEO and SCW. No difference occurred in AYB and CP (Fig.4) at $50 \mathrm{ml} / 100 \mathrm{~g}$ and $100 \mathrm{ml} / 50 \mathrm{~g}$. The total fresh weights of the controls were significantly greater $(\mathrm{P}<0.05)$ than those grown in the pollutants. The same arrays were observed in the biomass (total dry weight) and root lengths (Fig.5 \& 6).

Nodulation levels of AYB and CP varies inversely to the levels of SEO and SCW used. In Fig.7, Nodulation count in treatment with higher levels of SEO and SCW were significantly $(P<0.05)$ lower than those in the controls. Moreover, the impact of the pollutants was greater at chlorophyll contents of the crops in treatment $150 \mathrm{ml} / 0 \mathrm{~g}$ compared to other levels and the control. Effect of SEO on AYB chlorophyll increased with dose of SEO applied (Fig.8).
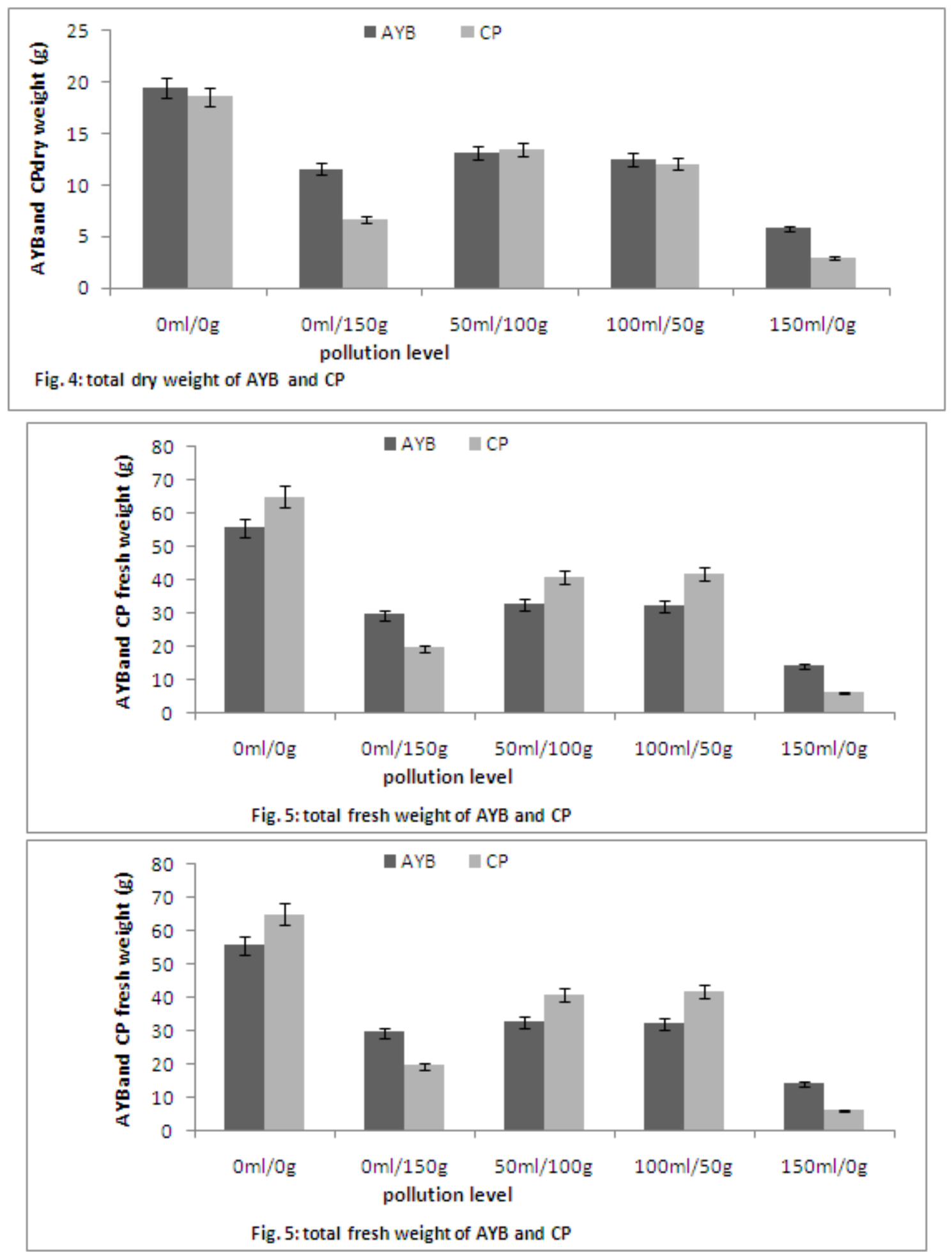

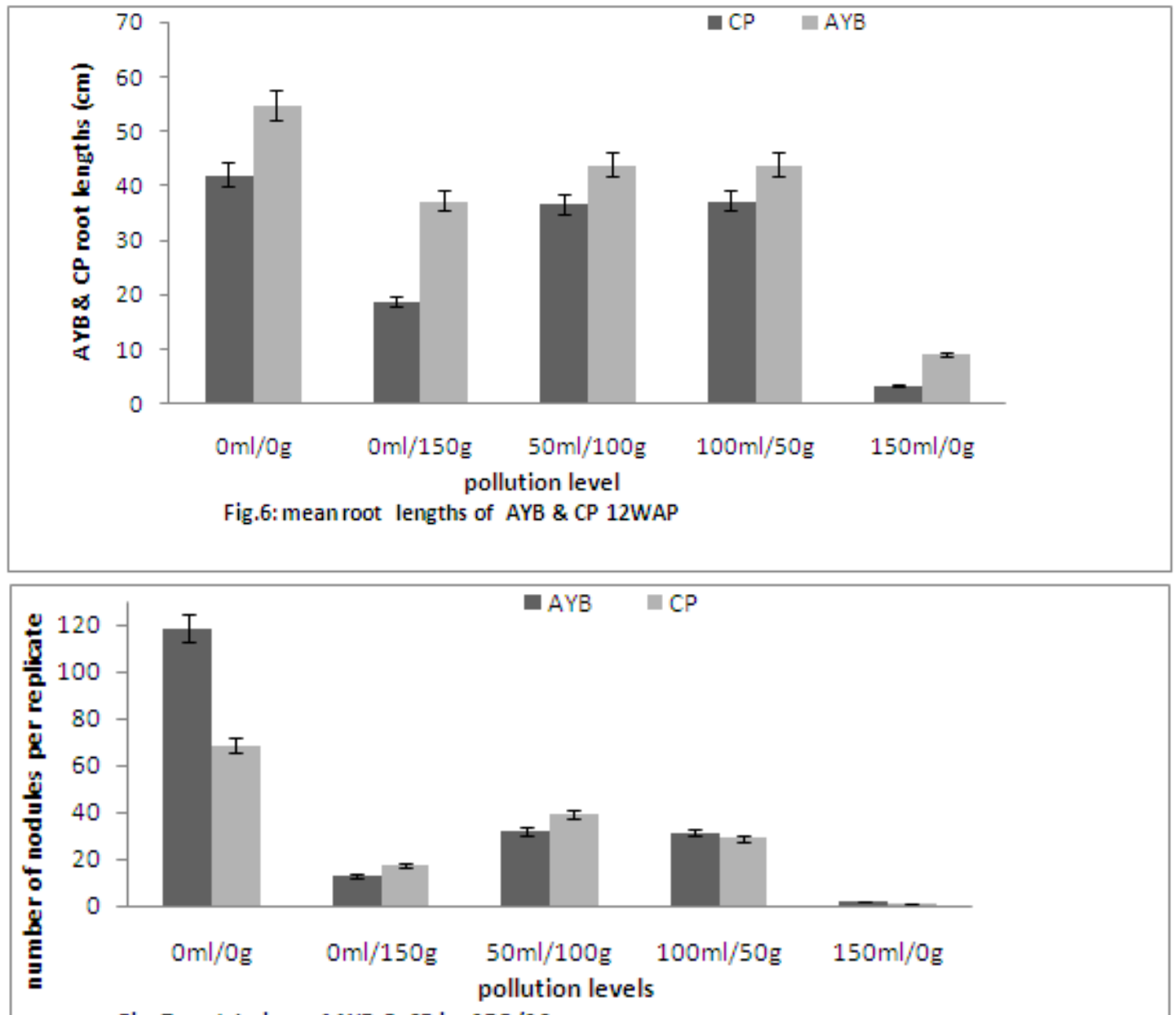

Fig. 7: nodulation of AYB \& CP in SEO/SC treatments.

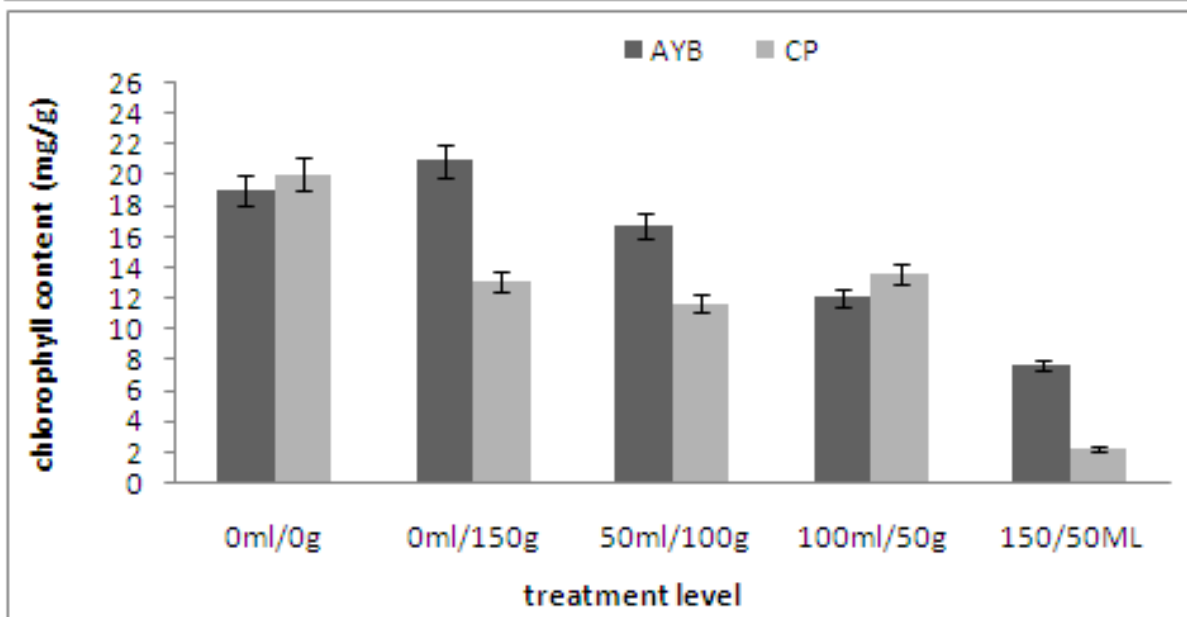

Fig. 8: chlorophyll content of CP \& AYB in various level of SEO/SC

\section{Discussion}

The result of growth performance (plant height, stem girth, number of level, biomass, root length, nodulation count and chlorophyll content) of AYB and CP as impacted by the various concentrations of SEO and SCW of (various proportions) in soil revealed that SEO and SCW in soil had significant adverse effects $(\mathrm{P}<$ $0.05)$ on $\mathrm{AYB}$ and $\mathrm{CP}$ in terms of aforementioned parameters. The impact being dosed dependent for the parameters. 
$\mathrm{CP}$ and $\mathrm{AYB}$ at higher concentration of SEO and SCW experienced reduction in height. This is similar to the finding of Kayode et al. [13] and Tanee and Ochekwu [6] who reported reduction in plant height due to SEO and SCW concentration respectively. However, AYB showed tolerance of SCW than CP indicating that the impact of SCW was severe on CP than AYB. Decrease in height and girth of plant with respect to increase in SEO dose is probably due to water deficit created by the pollutant which may have affected nutrient uptake [2]. The decrease in number of leaf on AYB and CP in SEO and SCW pollution indicated that the two pollutants inhibit the growth of legumes. Shedding of leaf results from inadequate nutrients needed to sustain leaf tempo which may invariably lead to reduction in the number of leaf in plants. Highest nodulation counts in both plants were observed in the control; suggesting that SEO/SC pollution depresses nodules formation in the plants. The lowest nodulation count for the two crops occurred in soil treated with only SEO; implying that the impact of SEO on nodule formation is greater than SCW.

High values in terms of root length, total fresh weight and total dry weight (biomass) of the controls were observed when compared with the various treatments suggesting that SEO and SCW in soil interfere with plant-water relationship through direct physical coating of root hairs, thereby affecting plant growth $[14,10]$. Reduction observed in chlorophyll level of AYB and CP in $150 \mathrm{ml} / 0 \mathrm{~g}$ is an indication that high concentration of SEO has adverse impact on chlorophyll synthesis. Similar result was reported by Adenipekun et al. [2], Odjegba and Sadiq [10].

\section{Conclusion}

In conclusion, it is clear that SEO and SCW in soil reduced plant growth performance especially at higher concentration. On this basis proper disposal of the automobile mechanic workshop waste should be done as not to dump them on farmlands. Also existing laws on environmental pollution should be reviewed with the aim of being made more effective and complementary with the present trend.

\section{References:}

[1]. Adenipekun C.O, Oyetunji O.J, Kassim L.Q, 2008. Effect of spent engine oil on the growth parameters and chlorophyll content of Corchorus olitorius Linn. Environmentalist 28: 446-450.

[2]. Adenipekun, C.O, Oyetunji, O. J, and Kassim, L. Q. 2009. Screening of Abelmoschus esculentus (L.) moench for tolerance to spent engine oil. J. of applied Biosci. 20: 1131-1137.

[3]. Adenipekun, C.O. and Kassim, L.Q, 2006. Effect of spent engine oil on some growth parameters and moisture content of Celosia argentea L. Nigeria J. Bot. 19(2): 318-324.

[4]. Tanee, F.B.G. and Anyanwu D.I. 2007. Comparative studies of the growth and yield of two Cassava lines (TMS 30572 \& TMS $30555)$ in a crude oil polluted habitat. Scientia Africana. 6(1): 81-84.

[5]. Anyanwu, D.I. and Tanee, F.B.G. (2008). Tolerance of cassava (var. TMS 30572) to different concentrations of post-planting crude oil pollution. Nigerian Journal of Botany. 21(1): 203-207.

[6]. Tanee, F.B.G. and Ochekwu, E.B. 2010. Impacts of different concentrations of spent carbide waste on the growth and yield of maize (Zea mays L.) and groundnut (Arachis hypogea L.). Global Journal of pure and applied sciences. 16 (4): $401-406$.

[7]. Andrew, A.S. Anna, A.R. and Tatjana, B.P. 2012. Spent carbide waste retains toxicity long term after disposal in caves and mines. Journal of soil sci. Moscow State University.

[8]. Tanee, F.B.G. (2011). Change in vegetation regeneration, species composition and diversity in a spent carbide waste polluted habitat. Int' J. of Applied Env. Sci. 6(3): 309-317.

[9]. Salf-ur, R.K.Y. Muhammed, Rashid, M. and Muhammed A. 2007. Responses of okra (Abelmoscus esculetus L. moench) to soil applied $\mathrm{CaC}_{2}-\mathrm{An}$ Innovative Approach. International Symposium on Prospects of Horticultural industry in Pakistan. Institute of Horticultural Science, University of Agriculture Faisalabad

[10]. Odjegba, V. I. and Sadiq, A.O. 2002. Effect of spent oil on the growth parameters, chlorophyll and protein levels of amaranthus hybridus L. The Environmentalists, 22:23-28.

[11]. Comar, C.L. and Zscheile, F.P. Jr., 1942. Influence of preparative procedure on the purity of chlorophyll components as shown by absorption spectra. Bot. Gaz., 102: 463-81.

[12]. Ogbeibu, A. E. 2005. Biostatistics - A practical approach to research and data handling Minder Publishing Company Ltd, Benin City, Nigeria.

[13]. Kayode, J, Olowoyo, O, and Oyedeji, A. 2009. The effects of used oil pollution on the Growth and Early seedling performance of Vigna unguiculata and Zea mays. Research J. of soil biology 1 (1): 15-19.

[14]. Emersion, R. N. 1983. Oil effects on terrestrial plants and soil: a review of vegetation assessment unit phytotoxicology section Ont. ARB-108-183- Phyto. 